\title{
Sosyo
}

Ekonomi

\section{Türkiye'de Sosyal Politika ve Koruyucu Aile Hizmet Modeli}

\author{
Leman ERDAL \\ lerdal@adu.edu.tr
}

\section{Social Policy and Foster Family Care Model in Turkey}

\begin{abstract}
The aim of this study is to assess the theory and practice of the foster family care model for the children/younsters "in need of protection and institutional care" by discussing the basic concepts and instruments of child care. Firstly, the concepts of social state and social policy will be described. The foster family care model which is accepted as a powerful tool in "being integrated into society" or "return to the family", for the children in need of protection has been supported by recent government. In this context, the importance and necessity of the foster family care model will be discussed, and the legal regulations related to the model will be provided. In the final part of the study, the application of Foster Family Care Model in Istanbul, which has an outstanding population density, and across the country will be presented with graphics based on statistical data, followed by some policy recommendations.
\end{abstract}

Keywords

JEL Classification Codes
: Social State, Social Policy, Child Care, the Foster Family Care Model.

H1, H11, H53, I38.

Özet

$\mathrm{Bu}$ çalışma, "devlet koruması ve kurum bakımı altındaki” çocuk/gençlere yönelik hizmetler kapsamında yer alan, Koruyucu Aile Bakım Modeli'nin, temel kavramları ve araçlarını tartışarak, teorik ve uygulamaya yönelik, incelenmesini amaçlamaktadır. Bu bağlamda ilk olarak, sosyal devlet, sosyal politika ve koruyucu aile kavramları tanımlanacaktır. Korunmaya muhtaç çocukların "topluma uyum sağlaması" ve "aileye dönüşü” için önemli bir araç olarak görülen, koruyucu aile hizmet modeli mevcut hükümet tarafindan önemle desteklenmektedir. Bu bağlamda korunmaya muhtaç çocuklar açısından, bu hizmetin önemi ve gereği tartışılarak; söz konusu model ile ilgili yapılan yasal düzenlemelere yer verilecektir. Çalışmanın son bölümünde koruyucu aile hizmet modelinin, nüfus yoğunluğu ile öne çıkan İstanbul ilinde ve ülke genelindeki uygulamasının, istatistik verilere dayalı grafikler yardımıyla sunumu ve politika önerilerine yer verilecektir. 
Leman ERDAL

172 


\section{Giriş}

Devletin temel unsurlarından biri olan millet/insan unsuru ekonomik kalkınma ve sosyal gelişmenin ana belirleyicileri arasındadır. Bilgi ve beceri düzeyi yüksek bireylerin oluşturduğu bir toplumun, beşeri sermayesi de zengin olacaktır. Birey, içinde yaşadığ toplumda klasik özgürlüklere sahip olmanın yanında (ruhsal, fiziksel ve sosyal anlamda) kişisel gelişimini sağlayacak eğitim, sağlık güvenlik gibi sosyal imkânları kullanma hakkına da sahiptir. Devletin, söz konusu hizmetlerin kalitesini ve erişilebilirliğini artırmak amacıyla yatırım yapması varlığının gereğidir. Zira devletin vatandaş/bireye karşı en önemli sorumluluğu, iyi yetişmiş ve topluma karşı sorumluluk sahibi birey olabilmesi için zorunlu olan temel ihtiyaçlarının, insan onuruna yakışan yaşam koşulları sunularak karşılanmasıdır.

Batı demokrasilerinde II. Dünya Savaşı'ndan sonra yapılan anayasalarda devletin, klasik fonksiyonları yanında, vatandaşların sosyal hakları ayrıntılı şekilde düzenlenmeye başlanmıştır. Devlet, vatandaşlarına insan onuruna yaraşır hayat standardı sağlamak; çocukları, gençleri, ebeveynleri, yaşlıları, özürlüleri, çalışamayacak durumda olanları korumak, yoksulluk ve gelecek korkusundan kurtarmaya yönelik sosyal güvenlik sistemlerini kurmakla yükümlü tutulmuştur. Devlete, başta eğitim ve sağllk olmak üzere sosyal güvenlik, sosyal hizmetler, konut alanlarında çok sayıda yeni görev ve sorumluluklar yüklenmiştir (Yolcuoğlu, 2012: 152-3).

Aile, toplumda bireyi her türlü tehlike ve risk faktörüne karşı koruyan bir kurumdur. Ancak değişen sosyal değerlere paralel bir değişim, aile kurumunda da yaşanmaktadır. $\mathrm{Bu}$ süreçte, kırsaldan kente göç ve sonrasında yaşanan yoksulluk, aile yapısının çözülmesi, boşanmalar ve evlilik dışı doğan çocukların sayısında artış gibi birbiri ardına yaşanan olaylar dizisi, üyelerine her türlü desteği veren "geleneksel ataerkil Türk aile yapısının", yerini bireyselliğin öne çıktı̆̆ "çekirdek aile" yapısına terk etmesine neden olmaktadır. Hatta daha da vahim olanı, çocuğu ile yaşayan tek veya evlenmemiş ebeveynlerin sayısının giderek artmasıdır.

Çalışmanın ana konusunu, devlet koruması altında bulunan çocuk ve gençlerin, fiziksel, ruhsal ve sosyal açıdan daha sağlıklı bireyler olarak yetişmelerini sağlayacak olan Kоrиуиси Aile Hizmet Modelinin uygulaması oluşturmaktadır.

Çalışmada, öncelikle sosyal-refah devleti, sosyal politika ve koruyucu aile kavramları tanımlanarak, tarihi süreçte geçirdiği değişime kısaca yer verilecektir. Ayrıca, sosyal refah devletinin gereği sosyal politikalara yön veren Aile ve Sosyal Politikalar Bakanlı̆̆ı'nın (ASPB) ${ }^{1}$ gönüllü kişi ve kuruluşlar ile birlikte hareket ederek, toplumdaki dezavantajlı gruplara destek veren uygulamalarından biri olan koruyucu aile hizmetinin

I 2011 yılında 633 No'lu Kanunla kurulan Aile Sosyal Politikalar Bakanlığı (ASPB), 1923 yılından bu yana Sosyal Hizmet ve Çocuk Esirgeme Kurumu (SHÇEK) adı altında hizmet veren kurumun yerini almıştır. 
çocuk ve gençlere sağladığı faydalar açısından önemi ve son dönemde teşvik edilen uygulanmaya yönelik yasal düzenlemeler ve uygulamaya yönelik istatistik bilgilere yer verilecektir.

Yasalar, öncelikli olarak çocuğun yetiştirilmesinde söz sahibi olan kişiyi sorumlu tutmak üzere onu, her türlü şiddet, kötü muamele ve cezaya karşı, korumaktadır. Çocuğun sorumluluğunu taşıyan kişinin, düzenli veya sürekli olarak sorumluluklarını ihmal ederek suç işlemesi durumda devlet, çocuğu koruması altına alarak bakımını üstlenmektedir. Yürürlükteki yasalar çerçevesinde, bireyin ve ailenin korunmasına yönelik mevcut sosyal politika hedeflerine göre, devlet koruması altındaki çocuk ve gençlere yönelik koruyucu aile hizmetinin (nüfus yoğunluğu nedeniyle) İstanbul'daki uygulaması baz alınmıştır. Son bölümde uygulamaya ilişkin rakamsal veriler ışığında, hizmetin çocuk ve gençlere faydaları ve uygulamada karşılaşılan zorluklara yer verilmiştir.

\section{Sosyal-Refah Devleti ve Sosyal Politika}

Literatürde, sosyal-refah devleti kavramı, genellikle vatandaşların sosyal durumlarıyla ilgilenen, refahın sağlanması amacıyla devletin ekonomiye müdahalesini öngören, vatandaşlarına yaşanabilir hayat standardı sağlayan devlet anlayışı olarak tanımlanmaktadır. Sosyal devlet; "insan onuruna saygı duyan, insanı bir değer olarak kabul eden devlet sistemi" olarak tanımlanmaktadır. Bireyi baskısı altında tutan sosyal ve ekonomik engelleri kaldırmayı üstlenen devlet, ekonomik ve sosyal bakımdan zayıf kesimleri koruyarak, onların maddî ve manevî gelişimleri için gerekli şartları sağlamak amacına yönelmiştir (Özler, 1995: 6-7).

Gelişmiş ülkelerde sosyal devletin görev tanımında, iç güvenlik ve adalet gibi kamu hizmetlerinin yanında, sosyal politikanın temel alanı, gelir dağılımı, sosyal güvenlik, eğitim, sağlık ve konut alanlarında hizmet sunumu da yer almaktadır. Devletin, toplumda refah düzeyinin artırılması; daha da önemlisi, artan refahın üretim faktörleri arasında adil dağıtılmasını temin etmek amacıyla "müdahaleci, düzenleyici ve geliri yeniden dağıtıcı" fonksiyonları öne çıkmaktadır. Devlet, çalışma koşullarıyla ilgili olarak, tüm nüfusu ve tüm riskleri kapsayan sosyal güvenlik ve sağlık sistemini kurarak, ilköğretimden yükseköğretime parasız eğitim imkânı ve "sosyal konut" projeleriyle vatandaşların temel ihtiyaçlarını karşılamaktadır. Ayrıca, toplumdaki dezavantajlı gruplar olarak ifade edilen bakıma muhtaç (hastalar, engelliler, yaşlılar, kimsesiz çocuklar, yoksullar) bireylerin ihtiyaçlarını karşılamak için bakanlık düzeyinde hizmet veren sosyal yardım ve sosyal hizmet kurumları oluşturulmaktadır. Toplumda hem ekonomik hem de sosyal refahın artırılması devletin kurumları tarafından sağlanmaktadır (Ersöz, 2011: 145-6).

Liberal görüşe göre sosyal-refah-devleti; doğal düzeni eşitlik, adalet ve güvenlik gibi kaygılarla bozarak, bazı kişi ve grupları kayıran bir yaklaşıma sahiptir. Söz konusu kayırmalar refah devletinin harcamalarını artırarak, vergileri yükseltmekte, devlet yapısını büyüterek, piyasayı zayıflatmakta ve özgürlükleri azaltmaktadır. Liberal görüş, sosyal 
devletin sunduğu hizmetlerin yalnızca devlet eliyle değil, aile, (kâr amacı güden veya gütmeyen) gönüllü özel sektör kuruluşları tarafından, sosyal sorumluluk paylaşımı yaklaşımıyla yerine getirilmesini savunmaktadır (Özdemir, 2009: 67-8). 1929 Ekonomik Kriz'i ve İkinci Dünya Savaş'1, liberal düşünceye dayalı olarak devam etmekte olan devlet ve ekonomi arasındaki ilişkileri bütünüyle değiştirmiştir. Ekonomik ve sosyal problemlerin devlet tarafindan üstlenilmesi gereği ve savaş esnasında devletin üstlendiği ekonomik rol, kamu sektörünün bu görevleri yerine getirmedeki başarısını kanıtlamıştır.

Sosyal devlet, kendisine yüklenen bu ulvi görevi yerine getirebilmek, kısa ve uzun vadeli hedeflerine yönelik strateji geliştirerek politika oluşturmak ve uygulamak zorundadır. Son zamanlarda ikiz kavramlar olarak ifade edilen sosyal dışlanma ve sosyal içerme konuları ve modern toplumun sosyal dışlanmayı azaltıcı politika önerilerine yönelik artan bir ilgi gözlenmektedir. Bu terimler üzerinde yapılan tartı̧̧malarda, sosyal dışlanma konusuna yönelik farklı çözümleri birbirine yaklaştırmaktadır. Bazıları konuyu refah ve sosyal politika açısından ele alırken; diğerleri konuyu ayrım-karşıtlığı ve insan hakları açısından ele almaktadır. Sosyal politika kavramı, literatürde farklı yaklaşımlarla, farklı tanımlamalara maruz kalmaktadır.

Özdemir (2007: 133-4) sosyal politika kavramını, "dar" ve "geniş" anlamda sosyal politika olarak iki şekilde tanımlamaktadır. Kapitalist düzende işçiler ve işverenler arasında ortaya çıkan çıkar çatışmalarını, çelişkileri ve dengesizlikleri gidermek, sınıflar arasında uyum sağlamak amacını güden yaklaşım, "dar" anlamıyla sosyal politikayı, ifade etmektedir. Sanayileşmenin doğrudan ya da dolaylı ürünü olarak görülen sosyal problemlerle savaşmak ya da bunları çözmek üzere geliştirilen kamu politikaları olarak tanımlanmaktadır. Sosyal politika "geniş" anlamıyla, sosyal alanlar ve bütün sosyal grupların sorunları ile ilgilenen, çözümler üreten uygulamalar olarak görülmektedir.

Titmuss, sosyal politikaya, "çalışan sınıflar, emekliler, kadın ve çocuklar gibi zayıf gruplar için fayda veya refah amaçlı bir yaklaşımla, kaynakları yeniden dağıtıcı bir işlev yüklerken; daha fazla refahın ve daha fazla faydanın sağlanmasında bir araç" olarak kabul etmektedir (Ersöz, 2011: 123-5).

Devlet, toplumda sosyal problemlere neden olan eşitsizlikleri düzeltme, dezavantajlı grupların şartlarını geliştirme ve zayıflara yardım sağlama amacıyla müdahalelerde bulunmaktadır. Bu bağlamda sosyal politika, "hizmet ve gelir sağlamak suretiyle vatandaşların refahına doğrudan tesir eden hükümet politikaları" olarak tanımlamaktadır. Gelişmiş ülkelerde devlet, sosyal politikalar aracılığıyla, piyasa 
yetersizlikleri $^{2}$ ortaya çıkmadan onları önlemeye çalışan önemli bir ekonomik aktördür (Ersöz, 2011: 135-6).

Sosyal politikayı devlete ait ve topluma yönelik politikalar dizisi olarak tanımlayan Koray (2007: 25-6) siyasî ve toplumsal yapıda yaşanan değişimin sosyal politika yaklaşımını da değişime zorladığını ifade etmektedir. Sosyal politika anlayışı ve uygulamalarını kökten değiştiren etkenlerin başında, piyasanın küreselleşmesinden doğan çok yönlü sorunlar ve etkileri; buna bağlı olarak devlet anlayışı ve yapısında ortaya çıkan bazı temel değişiklikler; üçüncü olarak da toplumsal yapıdaki değişimlerden kaynaklanan yeni sorunlar ve ihtiyaçlar olarak sıralanmaktadır (Tarabini, 2010: 2005-6).

Sosyal politikanın amacı, toplumun sosyal sorunlarına çözüm üreterek, sosyal yönden gelişmesini sağlayarak ekonomik kalkınmaya destek olmaktır. Burada, sosyal gelişmeden kasıt, üretim sürecinin temel unsuru olan bireyin; eğitim, sağlık, konut gibi sosyal amaçlı yatırımlarla desteklenmesi, yüksek istihdam düzeyini yakalama, gelirin adil dağılımı ve sosyal refahın sağlanmasıdır. İyi eğitilmiş, iyi ücret alan, her türlü sağlık ve konut problemi çözülmüş bir birey, daha sağlıklı, huzurlu ve istikrarlı bir toplum oluşturacak, verimlilik artacak, yani sosyal gelişme için yapılan harcamalar, ekonomik gelişme ve kalkınmanın da katalizör maddesi olacaktır. Sosyal politika bu anlamda, adalet, sosyal gelişme, toplumsal denge ve bütünleşme hedeflerini kapsamaktadır (Özdemir, 2007: 101-3).

Dünyada sosyal-refah-devleti ile bağlantılı olarak 21. yüzyılda ekonomik küreselleşme ve post-endüstrileşmenin etkisiyle sanayi toplumundan bilgi ve ağ toplumuna; Fordist üretimden esnek üretime; ulus devletlerden küreselleşmiş dünyaya; modern düşünceden post-modern düşünceye geçişin yaşandığı çok yönlü değişim devam etmektedir.

Küreselleşme, neo-liberalizm, ekonomik ilişkilerin uluslararası yaygınlaşması, ulus-devletin zayıflaması vb. gibi unsurlar 1980'li yılların başında bir taraftan refahın adil dağılımını olumsuz etkilemiş, geniş halk kitlelerinin daha fazla yoksullukla karşı karşıya kalması ve gelir dağılımının bozulmasına yol açarken; diğer yandan sosyal adalet ve sosyal politika anlayışında ulaşılan gelişmelerde bir durağanlık ve geriye gidişe neden olmuştur. Özellikle iş piyasaları, vergi, sosyal harcamalar ve sosyal koruma sistemlerine dönük baskıların artmasıyla birlikte devletlerin; sosyal güvenlik, eğitim, sağlık gibi hizmetleri sunan sosyal refah politikalarını yeterli düzeyde sunamamalarına neden olmuştur. Mevcut yönetim anlayışını meşru ve muktedir kılan koşulları aşındıran bu süreçte, artan ve karmaşıklaşan taleplere cevap vermekte zorlanan devlet, yeni arayışlar içine girerek daha etkin, akılcı ve verimli bir idari yapılanma arayışına girmiştir. 1970'lerden sonra sosyal

2 Piyasa başarısızlıkları teorisi, sosyal politikaların olmadı̆̆ durumda, piyasanın yoksullara yönelik minimum gelir koruma sistemleri ya da să̆lık ve işsizlik sigortası gibi bazı güvenceleri să̆layamamasını "yoksulluk" olarak tanımlamaktadır. 
politika anlayışındaki, merkeziyetçi yapıdan uzaklaşıldığı; ulus-devletin otorite ve yetkilerinin bir kısmını yerel yönetimler, gönüllü kuruluşlar ve diğer sivil toplum örgütleri gibi "ulus-altı" kurumlarla paylaşmaya başladığı gözlenmiş̧tir. Devlet dışındaki kurumların büyük rol üstlendiği refah çoğulculuğu yaklaşımına göre; kamu yönetim birimleri, sürdürmek durumunda olduğu sosyal-refah-hizmetlerinin planlanması, finansmanı ve denetimi görevlerini üstlenerek; hizmetlerin üretim ve dağıtımını toplumdaki diğer aktörlere bırakmaktadır. Küreselleşmeyle birlikte "Yeni Kamu Yönetimi Yaklaşımı", hukukun üstünlüğü, açıklı, saydamlık, sorumluluk, hesap verebilirlik, güvenirlik ve tutarlılık kavramlarını öne çıkarırken, devletin kararlarını, toplumun tüm kesimleriyle paylaşması istenir olmaya başlamıştır (Ersöz, 2011: 148-9).

Türkiye Cumhuriyeti tarihinde ilk kez 1961 Anayasa'sında "sosyal devlet" ifadesine yer verilmiştir. 1982 anayasasının Türkiye Cumhuriyeti'nin niteliklerini belirleyen 2. maddesinde aynı ifade tekrarlanmıştır. Ülkede küreselleşmenin getirdiği ekonomik düzene uyum sağlama, $A B$ üyeliğinin ön şartı olan Kopenhag Kriterleri ve ekonomik istikrarın gereği olarak yeniden yapılanma açısından liberal ekonomik düzen benimsenerek karma ekonomiden liberal ekonomiye doğru geçişe başlamıştır. Bugün büyük şehirlerde başlı başına bir sosyal sorun olarak kırsaldan kente göç olgusu; gecekondulaşma, ailede yapısal ve kültürel çözülmeler, işsizlik, sokak çocukları, madde bağımlılığı, suçluluk gibi diğer sosyal sorunları da beraberinde getirmektedir (Özdemir, 2009: 65-7).

Ersöz'e (2011: 156-7) göre; son y1llarda nispeten atılan olumlu adımlara rağmen Türkiye'de bugüne kadar sosyal devlet standardına ulaşılamamış ve "sosyal vaatler devleti" olmanın ötesine geçilememiştir. Ersöz, bir toplumda sosyal politika, sosyal yardım ve sosyal hizmetlerin düzeyinin o toplumun hayırseverlik duygularının kurumsallaşma düzeyine bağlı olduğunu ve devletin gönüllük ve hayırseverliği harekete geçirecek politikalara yönelmesi gerektiğini ifade etmektedir. Sosyal hizmetlerin sağlanmasında toplumun daha büyük sorumluluklar üstlendiği bu yeni yapı, temeli vakıf medeniyetine dayalı olan Osmanlı toplumunun mirasçısı olan Türkiye gibi yüksek bir hayırseverlik düzeyi ve gönüllülük potansiyeline sahip toplumlar için firsat olarak kabul edilmektedir. Osmanlı Devleti'nde önemli işlevler icra eden vakıflarla hayat bulan sivil toplum geleneğinin, Cumhuriyet Dönemi'nde işlevsiz kaldığına vurgu yapılmaktadır. Türkiye'de I. Dünya Savaşı'ndan itibaren dünyada olduğu gibi sosyal politika alanında, merkezi ve yerel hükümetlerin giderek artan oranda etkin olduğu görülmektedir. Temeli gönüllülük esasına dayanan sosyal yardım ve sosyal hizmetlerin (yaşlı, çocuk, madde bağımlısı, özürlü bakımı vb.) ancak gönüllü kişiler tarafından etkin bir biçimde yapılabilecek işler olduğu ifade edilmektedir. Devlet kurumlarının özel sektörden hizmet satın almasının, çok düşük ücretlerle çalışan eğitimsiz kişilerden, zaman zaman aile bireylerinin dahi birbirine gösteremediği hizmet ve şefkat beklenmesinin verilen hizmetin kalitesinin düşürülmesine yol açtığına; çocuk yuva ve yurtlarında yaşanan şiddet ve taciz olaylarının, bu kanıyı doğrulayan en açık kanıtları oluşturduğuna yer verilmektedir. 
Sivil toplum teorilerinde ifade edildiği gibi, demokrasinin başarısı, devlet gücünü denetleyen ve sosyal altyapıyı kuran bağımsız organizasyonları gerekli kılmaktadır. Yeni sosyal devlet anlayışında, devlet toplumsal baskı ve sosyal zorunluluk nedeniyle sürdürmek durumunda olduğu sosyal politika kapsamında sosyal hizmetlerin sağlanması fonksiyonunu bütünüyle terk ederek; geniş bir biçimde bu hizmetin üretim, dağıtım ve sunumunda özel sektör ve gönüllü sivil toplum kuruluşlarından yararlanmaktadır. Sivil toplum, uluslararası ve yerel aktörlerin kişiler ve gruplar arası güvene dayalı ilişkiler aracılığı ile demokratik prensipler inşa ettiği ulusal kurumlardır. Sivil toplum, faklı bireysel çıkarların ve sosyal durumların harmonize olduğu fikirlerin ifade bulduğu, esasen devletin dışında faaliyet gösteren ancak kamu ve özel sektörün sentezi olarak da kabul edilen, toplumda sosyal düzeni ve etik değerleri koruyan, devleti ve onun antidemokratik uygulamalarını denetlerken; başarılı işleyişine de destek veren bir yapıya sahiptir (Şimşek, 2004: 48-56; Sommerfeldt, 2013: 4-5).

Türkiye'de sosyal politika hedefleri arasında olan koruyucu aile modelinin, hizmetin üretim, dağıtım ve sunumunda özel sektör ve gönüllü sivil toplum kuruluşlarından yararlanılması suretiyle teşviki ve uygulamasının, çocuk koruma ve bakım hizmetinin ifasında olumlu sonuçlar vereceği beklenmektedir.

\section{Koruyucu Aile Hizmet Modeli}

İnsan olmasının ötesinde toplumun geleceği olan çocuk/gençlere verilen önem ve koruma, devletin temel görevi yanında varlığını sürdürebilmesinin ön koşuludur. Ekonomik gelişme ve kalkınma, toplumda ekonomik anlamda bir dönüşüme paralel olarak, merkezinde, "aile" kurumu olan sosyal yapıyı da dönüştürmektedir. Aile kurumundaki dönüşümden kaçınılmaz olarak etkilenen ve geleceğin büyükleri olan çocuk/gençlerin toplum ve devlet tarafindan korunması gereklidir (Taşcı, 2010: 178-9). Çocuklarına değer veren, onlara kendilerini geliştirmeleri için firsatlar sunan toplumlar, sağlıklı nesiller inşa edebilen zengin bir kültüre sahip toplumlar olarak tanımlanırken; çocukların, ihmal, istismar ve kötü muameleye maruz kaldığı toplumlar, geri kalmış toplumlar arasında sayılmaktadır. Zamanın getirdiği zorluklarla zayıflayan ve dağılan aileler, çocuklarını koruyamaz duruma geldiklerinde; devlet, çocuğu koruma altına almaktadır. Devlet koruması altındaki çocukların ihtiyaçları; yaş, engelli olma veya mental sağlık durumu, (rızaya dayalı veya mahkeme kararıyla) korunmaya alınma nedeni, (bakım altındaki çocuğun yararlandığı) hizmet modeli, kalitesi ve hizmetten yararlanma süresi, eve dönüş yaşına göre değişen, çok karmaşık ve kapsamlı bir konudur.

Dünyada ve Türkiye'de uygulanan piyasa odaklı liberal politikalar, devleti küçültürken sosyal güvenlik alanındaki kamu harcamalarını da sınırlandırmıştır. İşsizlik ve düşük gelir gruplarının artmasına neden olan bu uygulamalar, toplumun çoğunluğunda kamu hizmetlerinden yararlanma oranını da düşürmüştür. Sosyal, ekonomik ve siyasi anlamda yaşanan yoksulluk ve düşük gelir, önce ailelerin dağılma ve parçalanma sürecine neden 
olması; sonrasında da süreçten en fazla etkilenen çocuklar üzerindeki olumsuz etkisi açısından önemle üzerinde durulması gereken konudur. Diğer yanda, korunmaya muhtaç çocuklar açısından sosyal-refah devleti ne kadar sosyal olursa olsun; çocuğun ailesinin yerini tutmada yetersiz kalacağı ifade edilmektedir. Bu bağlamda, 28497 Sayılı Koruyucu Aile Yönetmeliği (1. ve 2. madde), çocuğun yetiştiği fiziksel çevre açısından güvenlik ve görünümü nedeniyle koruyucu ailenin önemine vurgu yapmaktadır (Sugur \& Doğru, 2010: 132-6).

Son zamanlarda sosyal hizmetlere ayrılan kamu harcamaları önemli bir çalışma konusu olmuştur. Koruyucu aile hizmet modeli, korunmaya muhtaç çocuklar açısından hizmet kalitesini artırırken, maliyetleri düşüren; hem aile hem de toplumda yoksulluk ve düşük gelir nedeniyle yok olma sürecine girmiş dayanışma ve kaynaşmayı yeniden artıracak önemli bir araç olarak görülmektedir.

\section{1. Çocuk Bakımında Koruyucu Aile Hizmet Modelinin Gereği}

Ekonomi politikasıyla desteklenen sosyal politikanın hedefi, sosyal hizmetlerin alanını genişleterek, dışlanan kesimlerin hepsine ulaşabilmektir. Toplumda dışlanan çocuklar Bakanlık tarafından, devlet koruması altına aldıktan sonra; toplu kurum bakım yerine, ilgili birimlerin izleme ve gözetiminde; onlara aile ortamı sunacak koruyucu ailelerin yanına kısa veya uzun süreli yerleştirilirken, öz aileleriyle ilişkileri de devam ettirilmektedir. Miller (2013: 141), koruyucu aileyi “çocukların kendi evlerinin dışında 24 saatlik aile (yerine) bakımı" olarak tanımlamaktadır. Koruyucu aile, kendi evlerinde biyolojik ailesi yanında kalamayan çocuk/gençlere "aile benzeri” bir çevre oluşturmaktadır.

Aile ve çocuklar üzerine yapılan çalışmalarda ailelerinden ayrılan çocukların, \%80 oranında psiko-sosyal sorunlar yaşadığ1; kurum bakımına alınanların; koruyucu aile yanında olanlara, göre daha fazla sorun yaşadığı tespit edilmiştir. Büyük ölçekli, çok geniş yelpazede birbirini tamamlayan, kesintisiz bir dizi hizmeti içeren kurum bakımındaki ihtiyaçları kesintisiz ve yeterli düzeyde karşılanamayan çocuk/gençler, hayat deneyimi ve kaliteden yoksun eğitimler sonucu; işsiz kalma, evsiz olma, madde bağımlılı̆̆ , uygunsuz hayat koşulları veya hapishaneye mahkûm olma gibi olumsuzluklar yaşamaktadır. Toplu bakım hizmetlerinin bu denli kötü koşullara sahip olmasının nedeni, hizmetin koordinasyonunun kötü olması ve "kaderine terk edilmesi" olarak gösterilmektedir (Miller, 2010: 142-3).

Kurum bakımındaki çocuk/gençler; ebeveynlerin ölümü, hastalığı gibi nedenlerle güdümsüz desteksiz kalan; aile içi geçimsizlik, anlaşmazlıkla sonuçlanan boşanma, terk süreci ve sonrasında olumsuz etkilenen çocuk/gençlerden oluşmaktadır. Çocuk/gençler fiziksel, psiko-sosyal gelişimleri karşılanamadığından, uyumsuz, suçlu ve korunmaya muhtaç haldedir (Miller, 2013: 134-5). Araştırmalar, özel bakım gerektiren bir sağlık sorunu olmadığı sürece, küçük çocukların, toplu bakım hizmetine tabi tutulmamaları gerektiğini gösteren sonuçlar vermektedir. Beyin gelişiminin tamamlanmasıyla bebeklik ve ilk 
çocukluk döneminde; güven duygusu, kendine güven, bilinç gelişimi, empati kurma, problem çözme, odaklanarak öğrenme ve dürtü kontrolü gibi kazanımları da gelişmektedir. Koruyucu aile hizmeti, ilk çocukluk dönemindeki, kritik nörolojik ve bilişsel gelişim açısından bakım kalitesinin yüksek olması nedeniyle çocukların bir taraftan bilişsel gelişim, eğitim olanakları, okul kazanımları ve sosyal becerilerini artırırken, diğer taraftan kurum bakımı altında olan çoğu çocuğun yaşadığı iletişim problemlerini de azaltmaktadır. Araştırmalar çocuğun, aile bireyleriyle ilişki kurmasının etnik, kültürel, dil ve dini ya da manevi kültürünü tanıması ve gelişimi açısından önemine dikkat çekmektedir. Örneğin, Romanya'da, koruyucu aile yanında kalan 4,5 yaşındaki çocukların IQ düzeylerinin, yetimhanede kalanlardan 10 puan fazla olduğu gözlenmiş̦tir (CSSP, 2009).

Bebeklikte ilk bakım veren kişiyle ilişkisi ve etkileşiminin çocuğun bilişsel ve fiziksel gelişimi; duygusal kontrol ve olgunluğu; iletişim becerileri üzerindeki olumlu etkileri yapılan araştırmalarla desteklenmektedir (Özgür, 2011: 100-1). Bu bağlamda çocuk gelişiminde önemli bir kavram olan, "bağlanma" üzerine yürütülen araştırmalarda, çocukluktaki bağlanma sisteminin temel özelliklerinin yetişkin ilişkilerinde de sürdügü; insanların duygularını düzenleme biçimleri, stresle başa çıkma yolları, ilişki tatmini ve depresyona kadar birçok konuda bağlanma ilişkileri geçmişinin anlamlı mesajlar verdiğine işaret edilmektedir. Bowlby'nin geliştirdiği anne-çocuk arasındaki bağlanma ilişkisini ve bu ilişkinin yetişkinlik dönemindeki etkilerini de açıklayan Bağlanma Teorisine göre; bebek, yaşamın ilk yıllarında bakıcısının verdiği tepkileri ve yakınlık isteğini gösteren davranışlarını, zihinsel temsiller olarak kodlar. Bakıcının bebeği algılayışı, ona yönelik olan davranış biçimleri, bebeğin kendisiyle ilgili "benlik algısl" geliştirmesine; bebeğin gözlemlediği bakıcı davranışları ve yaklaşımları da bebekte başkalarına yönelik, "başkası algısını" ortaya çıkarmaktadır. Bu algılar, bebeğin hayatının ilerleyen dönemlerinde içsel bir model olarak kurduğu ve kuracağı ilişkileri etkilemektedir. Bowlby, kaynağını bebeklikte bakıcıyla olan ilişkiden alan içsel çalışan modellerin değişmez nitelik taşıdığını, kuşaktan kuşağa aktarılarak bireylerin tüm yaşantılarında etkili olduğunu savunmaktadır. Yetişkinlerin kişilik problemlerinden nevrotik düzeydeki semptomlarına; evlilik problemlerinden çocuk yetiştirmede yaşanılan sorunlara kadar birçok yetişkin işlevsizliğinin içsel çalışan modellerin etkisi altında gerçekleştiğini iddia etmektedir (Özgür, 2011: 101-2).

Çocuğun fiziksel, ruhsal ve duygusal gelişimini tamamlamasının, ona sevgi dolu, sıcak bir ortam sağlayan aileye sahip olmasıyla mümkün olacağı vurgulanmaktadır. Ayrıca maruz kaldığı ihmal ve istismara bağl1, olarak gelişen hiperaktivite, kaygı, düşünmeden hareket etme, uyku bozukluğu gibi yaşadığı strese bağlı rahatsılılılarla baş edebilmesi için onu koşulsuz seven, değer verdiğini hissettiren bir yetişkinin desteğiyle aşabileceği ifade edilmektedir (Vinnerljung \& Hjern, 2011; Miller, 2013: 134-5). Çocuğun üstün yarar1, fiziksel ve ruhsal gelişimi açısından gerekliliği akademik çalışmalarla da desteklenen koruyucu aile hizmeti modeli, mevcut hükümetin desteklediği ve teşvik ettiği önemli bir uygulamadır. 


\subsection{Koruyucu Aile Hizmet Modelinin Uygulama Süreci}

Çocuk/gençlere yönelik sosyal politika ihtiyacının en kapsamlı faktörü olarak ekonomik çerçeve sayılmaktadır. Özellikle gelişmiş ülkelerde nüfus artışı yavaşlarken, dünyanın 18. büyük ekonomisi olan Türkiye'de genç nüfusun toplam nüfusa oranı sürekli artmaktadır. Ekonomik gelişme ve kalkınma yarışında, sürdürülebilirlik açısından, toplumların, beşeri sermaye zenginliğinin önemi bilinmektedir. Ülkede yaklaşık 75 milyonu aşan nüfusun, \%24,9'u (0-14) yaş ${ }^{3}$ grubu aralığındadır. Bu oran, demografik açıdan ülke nüfusun önemli bir bölümünü çocuk ve gençlerin oluşturduğunu göstermektedir (TÜiK, 2013). Ülke genelinde (Tablo: 1) çocuğa yönelik hizmet veren kuruluşlarda yaklaşık 13.772 çocuğa bakım ve koruma hizmeti verildiği (ASPB-2012) göz önüne alındığında, konunun önemi daha da belirginleşmektedir.

Toplumun gelişimini sürdürmesini sağlayan çocuk/gençlerin bedensel, zihinsel, duygusal, sosyal ve ahlâkî gelişimi ve yetişmesi ilgili eğitsel önlemlerin alınması yanında, onun aile ve toplum içindeki yerini düzenleyen hukuk kuralları da önemli bir yere sahiptir. Toplumda doğal güçsüzlüğü dolayısıyla gereksinimleri karşılanmamış, haklarından yoksun bırakılmış, toplumun (ana baba da dâhil) her kesimince her türlü baskıda bulunabileceği bir nesne olarak algılanan çocuğun, korunması ancak hukuk kurallarıyla mümkündür. Söz konusu kuralların çocuğun onuru, saygınlığı ve özgürlüklerine uygun olmasının, çocuğa olduğu kadar topluma da fayda sağlayacağı ifade edilmektedir (Akyüz, 2013: 456-7).

Türkiye'de, 14 Aralık 2012 tarih ve 28497 Sayılı Koruyucu Aile Yönetmeliği ${ }^{4}$, devletin yetkili görevlilerinin denetiminde gönüllü ailelerin vereceği koruyucu aile hizmetini düzenlenmektedir. Yönetmelik dayanağını ${ }^{5}$, Türkiye'nin de taraf olduğu, Birleşmiş Milletler Çocuk Hakları Sözleşmesinin 20. maddesinden almaktadır. Düzenleme, koruyucu ailelere çocuk ve gençlerin bakımı sırasında ve sonrasında aile eğitimleri vererek işbirliği ve destek verilmesini öngörmektedir (R.G., 2013).

Yönetmeliğin amacı, md.1'de "korunmaya muhtaç çocukların korunmalarını gerektiren süre içerisinde aile ortamında yetiştirilmesine yönelik koruyucu aile hizmetlerinin uygulama esaslarını, Bakanlı ile koruyucu ailenin yetki ve sorumlulukların belirlemek, hizmetin etkin bir şekilde yürütülmesini sağlamak" olarak ifade edilmektedir. Yönetmeliğin 2. maddesinde yer alan "çocuğun durumuna en uygun koruyucu aile seçimini,

318857 179, Bu rakamı 18 yaşına kadar yükseltildiğinde, oran daha da artacaktır.

4 Resmi Gazete Tarihi: 28.11.1983, Resmi Gazete Sayısı: 18235, Korunmaya Muhtaç Çocukların Tespiti, Inceleme Korunma Kararlarının Alınması ve Kaldırılmasına İlişkin Yönetmelik.

5 24/5/1983 tarihli ve 2828 Sayll Sosyal Hizmetler Kanununun 22 nci ve 23 üncü maddeleri ile 3/6/2011 tarihli ve 633 Sayılı Aile ve Sosyal Politikalar Bakanlığının Teşkilat ve Görevleri Hakkında Kanun Hükmünde Kararnamenin 2 nci maddesinin birinci fikrasinın (c) ve (d) bentleri, 8 inci maddesinin birinci fikrasının (ç), (d) ve (l) bentleri, 22 nci maddesinin birinci fikrasinın (d) bendi ile 28 inci ve geçici 6 nct maddelerine dayanılarak hazırlanmıştır. 
koruyucu ailenin eğitimini, sorumluluklarını, idare ile olan ilişkilerini, hizmetin işleyiş̧ini, koruyucu aileye talep halinde bu hizmetin karşıllğ iliş̧kin esasları" ifadesiyle yönetmeliğin kapsamını çizilmiştir (RG, 2013). Kapsamlı ve etkili bir planlamayla birlikte yeni yönetmeliğin uygulanması sonunda daha iyi sonuçlar alınacağı beklenmektedir.

Dünya üzerinde çocuklarının bakımını yapamayan birçok aile, maddi ve sosyal anlamda desteğe ihtiyaç duymaktadır. Bazı aileler, yakın akraba, arkadaş, komşu, yardım kuruluşları aracılığı ile destek bulsalar da; bu yardımların uygunsuz ve yetersiz olması nedeniyle çocukların korunma ihtiyacı devam etmektedir. Çocukların acil korunma ihtiyacı içinde olduğu bu süreçte, madde bağımlılığı, mental hastalıklar, yetersiz barınma koşulları, aile içi şiddet gibi çoklu risk faktörlerine maruz kalmaları yetkilileri, çocuğu aileden uzaklaştırma tedbirleri almaya yöneltmektedir (CSSP, 2009; Akyüz, 2013: 467-8). Çocuğun üstün yararını gözeterek bakım ve koruma sağlamayı amaçlayan çocuk koruma hizmeti, çocuğun içinde bulunduğu çevreden kaynaklanan ihmal, istismar risklerini azaltmayı ve gerektiğinde onu aileden uzaklaştırmayı da içermektedir. (CSSP, 2009).

Sosyal hizmetlerde çocuk koruma sistemi ve koruyucu aile hizmeti, çocuğun öncelikle ailesi yanında bakım ve korunması için alınabilecek önlem ve hizmetleri, bu alanda geliştirilecek sosyal politika, yasal düzenlemeler (ailenin güçlendirilmesi ve desteklenmesini amaçlayan), her türlü karar ve uygulamaları kapsamaktadır (Karataş, 2007: 9-12). Araştırmalar, devlet koruması altında ve kurum bakımında olan çocukların, büyük ölçekli ve karmaşık kurum bakımından kaynaklanan finansal engeller gibi risklere maruz kaldığını; buna karşın toplumda dezavantajlı nüfusa karşı pozitif sonuçlar görme beklentisi olduğunu göstermektedir. Aile dışında bakım gereken durumlarda, aile bağlarının devam ettirilmesinin bakım hizmetinde daha iyi sonuçların alınmasına katkı sağladığı ifade edilmektedir (CSSP, 2009).

Çocuk korumada en önemli ve gerekli hizmet modelini oluşturan kurum bakımının, nitelikleri, sıklığı, toplumun içinde bulunduğu sosyal, ekonomik ve siyasi koşullarına göre değişmektedir. İsveç, Almanya, İspanya ve İngiltere gibi bazı ülkelerde çocuk koruma hizmetinin öncelikle aileye yardım ve destek sağlama şeklinde başlatılıp, sonrasında veya bu hizmetin mümkün olmadığı durumda da koruyucu aile modeli, çocuk evlerinde bakım veya evlat edinme modeli uygulandığı gözlenmektedir. Araştırmalar evlat edinme seçeneğinin, çocuğun ilerideki hayatının risk ve kazanımları açısından en uygun bakım şekli olduğunu göstermektedir (Del Valle at all. 2009: 847-9; Vinnerljung \& Hjern, 2011: 1905-6). Ancak Türkiye'de de, dünyada olduğu gibi, ebeveynlerin izin vermemesi nedeniyle bu seçenek sıklıkla sunulamamaktadır.

Aile Sosyal Politikalar Bakanlığı'na (ASPB) bağlı hizmet veren Sosyal Yardımlar Genel Müdürlüğü (SYGM) ve Çocuk Hizmetleri Genel Müdürlüğü, toplumda dışlanan kesimlere, özellikle de çocuklara, aile çevresinde sağlıklı bireyler olarak yetişmeleri için hizmet vermektedir. Bakanlık, çocuk/gençlerin öz aileleri yanında yetişme şansını yeniden 
kazandırmaya yönelik olarak, öz ailelere sosyo-ekonomik destek hizmetini sunmakta; bu şansın oluşturulamadığı durumlarda da, onların aile ortamında korunmalarını sağlayacak evlat edinme ve koruyucu aile hizmetlerini sunmaktadır. Uygulamada bakım ve korunmaya muhtaç çocuk için (ister sağlıklı, ister özürlü olsun) en ideal bakım modeli olan "aile ve çevresi yanında bakım”, mevcut hükümetin desteklediği bir uygulamadır (ASPB-2014). Bu nedenle Bakanlığın yeni sosyal politika yaklaşımında korunmaya muhtaç çocuklar için öncelikle, öz aileye destek verme seçeneği tercih edilmektedir. Bu amaçla kısa dönemde yoksulluğun giderilmesi; uzun dönemde iyi beslenme yoluyla çocukların daha sağlıklı bireyler olmasına destek amacıyla Şartlı Nakit Transferi (ŞNT) programları uygulamaya konulmuştur. ŞNT paraları evde daha fazla söz sahibi olması ve aldıkları parayı daha çok çocukları için harcamaları nedeniyle annelere verilmektedir (ASPB-Rapor, 2012). Bakanlık bünyesindeki SYGM, muhtaç ailelere sosyo-ekonomik destek adı altında verdiği; gıda, barınma ve yakıt desteği, çocukların aileleri yanında büyümesini sağlamaktadır. Böylece kısa dönemde hane halkının tüketim seviyesini arttırarak anlık yoksulluğun etkilerinin hafifletilmesi hedeflenmektedir. Türkiye'de 2011 yılında sosyal harcamaların (sosyal yardım ve hizmetler) GSMH'ya oranı \%1,42 olarak gerçekleşmiştir. 2012 yılındaki toplam harcamalar da 1.526.227.980.-TL olarak gerçekleşmiştir (ASPB-2012 Bülten: 2013: 7-9).

Aile yanında bakımın mümkün olmadığı durumda, devlet korumasına alınan çocuk için kurum bakımı, evlat edinme ve koruyucu aile yanında bakım hizmet modeli seçenekleri değerlendirilmektedir. Kurum bakımı gerekliyse, çocuk veya gençler için en uygun kurum seçilmektedir. Bakanlık öncelikler doğrultusunda aşağıdaki hedeflere ulaşmayı planlanmaktadır.

1. Ailenin korunması ve yeniden birleştirmek için aileye (maddi) destek sağlanması,

2. Evlat edinme (ömür boyu aile bağının oluşması),

3. Koruyucu aile bakım ve desteği (akraba yanında koruyucu aile modeli desteklenmektedir),

4. Ev dışında bakım alan çocukların bakım koşullarının iyileştirilmesi ve gençlerin ergenliğe geçiş döneminde desteklenmesi.

Bakanlık, evlat edinme seçeneğinde fiziksel ve ruhsal gelişim sürecini yaşayan çocuğun uzun süren bürokratik işlemler ve yaşanan sıkıntılar nedeniyle mağdur olmasını önlemek amaciyla koruyucu aile hizmet modelini tercihten ziyade bir gereklilik olarak görmekte ve kurum bakımında zaten yüksek olan kaliteyi artırmaktan ziyade, koruyucu aile hizmetinin teşvikini tercih etmektedir. Bu amaçla kurum bakımının çok gerekli olduğu durumlar dışında ailenin de rızası alınarak, kurum bakımı altındaki çocuklar için, alternatif olan koruyucu aile hizmet modeline başvurulmaktadır (ASPB-2013).

Ev dışında bakım alan çocukların bakım koşullarının iyileştirilmesi ve gençlerin ergenliğe geçiş döneminde desteklenmesi amacına yönelik olarak, 5395 Sayılı Çocuk 
Koruma Kanununun, 5. maddesi 1(c) bendi, devlet koruması altındaki çocukların bakımını düzenlemektedir. Kanun, korunmaya muhtaç çocuklar hakkında alınacak tedbirler ile suça sürüklenen çocuklar hakkında uygulanacak güvenlik tedbirlerinin usul ve esasları, çocuk mahkemelerinin kuruluş, görev ve yetkilerine ilişkin hükümleri içermektedir (ASPB-2012). 14 Aralık 2012 tarih ve 28497 Sayılı Koruyucu Aile Yönetmeliği'ne göre, koruyucu aile yanına yerleştirilecek çocuk için, acil koruma kararı tedbirlerinin alınması önceliklidir. Yeni düzenlemeyle, 28497 Sayılı Koruyucu Aile Yönetmeliğinin 10. maddesi gereği, koruyucu aile olmak isteyenlerin, aile eğitimine tabi tutulması uygulaması son aşamasına gelmiştir. Düzenleme, sırasıyla akraba veya yakın çevre koruyucu aile modeli, uzun vadeli koruyucu aile modeli, geçici koruyucu aile modeli ve profesyonel koruyucu aile modelini kapsamaktadır (RG-2013).

Bakanlığın 2012 stratejik planında da yer alan ve önemle üzerinde durduğu koruyucu aile hizmet modeli uygulamasının desteklemesinin iki temel sebebinden birincisi, devlet kurumlarında bakım maliyetinin çocuk başına 3500-5000 TL arasında değişen rakamlarda olmasına karşın, koruyucu aile yanında kalan bir çocuğun devlete maliyetinin Tablo 2'de de görüldüğü gibi bu rakamların altında kalmasıdır. Ayrıca kurum bakımı süresi ne kadar uzun olursa, çocuğun aile yanına dönüşü, topluma veya çevreye uyum süreleri de o kadar zor ve sıkıntılı olmaktadır. İkinci olarak, çocuk istismarını önlemek amacıyla sosyal çalışma görevlilerinin koruyucu aileleri denetlemeleri daha kolay olduğu için, toplu bakım kurumları, daha küçük birimler ve koruyucu aile hizmet modeline yoğunlaşmaktadır (ASPB2013).

Tablo: 1'de Türkiye'de, 2012 Aralık ayı itibariyle, çocuk/gençlere hizmet veren kuruluşlardaki mevcut durum, devlet koruması altındaki çocukların kaldığ kurum sayısı, kapasitesi ve $0-18$ yaş aralığında kurumlarda kalan çocuk/gençlerin sayıları verilmiştir. Ülke genelinde, Tablo: 1'de görüldüğü gibi, çocuk/gençlere yönelik hizmetler, farklı hizmet birimlerince verilmektedir. Çocuk/gençlere hizmet veren kuruluşlar ve özellikleri aşağıdaki gibidir:

- Çocuk Yuvaları: 0-12 yaş arası korunmaya muhtaç çocukların, bedensel, eğitsel, psiko-sosyal gelişimlerini, sağlıklı bir kişilik ve iyi alışkanlıklar kazanmalarını sağlamakla görevli ve yükümlü yatılı sosyal hizmet kuruluşlarıdır. Gerekli durumlarda 12 yaşını bitirmiş korunmaya muhtaç kız çocukları da yuvalarda bakım almaktadır.

- Yetiştirme Yurtları: 13-18 yaş arası korunmaya muhtaç çocukları korumak, bakmak ve bir iş veya meslek sahibi edinmeleri ve topluma yararlı kişiler olarak yetiştirilmelerini sağlamakla görevli ve yükümlü olan yatılı sosyal hizmet kuruluşlarıdır.

- Sevgi Evleri: En fazla 12 çocuğun üçer kişilik odalarda kaldığı, çocukların yaşlarına uygun gelişim ihtiyaçları dikkate alınarak site içerisinde inşa 
edilen, müstakil villa tipi evlerden oluşan, aile ortamına benzer yapı ve ilişki sisteminde hizmet veren yatılı sosyal hizmet kuruluşlarıdır.

- Çocuk Evleri: Her ilin sosyal-kültürel ve fiziksel yapısına ve çocuk yetiştirmeye uygun bölgelerinde, tercihen il merkezinde, okullara ve hastanelere yakın apartman dairesi veya müstakil dairelerde $0-18$ yaş grubu 5 veya 8 çocuğun bir ev ortamı oluşturularak bakıldığı hizmet modelidir.

Tablo: 1

Çocuğa Yönelik Hizmet Veren Kuruluşlar ve Mevcut Durum (Aralık 2012)

\begin{tabular}{|l|r|r|r|r|}
\hline Kuruluşun Adı & \multicolumn{1}{|c|}{ Kurum Sayısı } & \multicolumn{1}{c|}{ Kapasite } & \multicolumn{1}{c|}{ Kayıtlı } & Fiilen Kalan \\
\hline Çocuk Yuvası (0-6) & 7 & 495 & 536 & 303 \\
\hline Çocuk Yuvası (7-12) & 20 & 1227 & 1396 & 918 \\
\hline Çocuk Yuvası (0-12) & 19 & 1857 & 2476 & 1444 \\
\hline Ara Toplam & $\mathbf{4 6}$ & $\mathbf{3 . 5 7 9}$ & $\mathbf{4 . 4 0 8}$ & $\mathbf{2 . 6 6 5}$ \\
\hline Çocuk Yuvası ve Yetiştirme Yurdu (0-18) & 14 & 1636 & 1968 & 1269 \\
\hline Sevgi Evi (0-18) 393 Villa tipi ev & 45 & 4019 & 5112 & 3301 \\
\hline Erkek Yetiştirme Yurtları & 48 & 3203 & 3996 & 2350 \\
\hline Kız Yetiştirme Yurtları & 17 & 998 & 1099 & 606 \\
\hline Yurt Ara Toplam & $\mathbf{6 5}$ & $\mathbf{4 . 2 0 1}$ & $\mathbf{5 . 0 9 5}$ & $\mathbf{2 . 9 5 6}$ \\
\hline Toplam & 170 & 13.435 & 16.583 & 10.191 \\
\hline Çocuk Evi (0-18) & 649 & 3814 & & 3581 \\
\hline Genel Toplam & $\mathbf{8 1 9}$ & $\mathbf{1 7 . 2 4 9}$ & $\mathbf{1 6 . 5 8 3}$ & $\mathbf{1 3 . 7 7 2}$ \\
\hline
\end{tabular}

Kaynak: ASPB 2012 Ylllk Faaliyet Raporu.

Bakanlık, Çocuk Hizmetleri Genel Müdürlüğü, stratejik plan hedeflerine yönelik olarak, klasik koğuş sistemi olarak bilinen yetiştirme yurdu ve çocuk yuvası olarak bilinen kurumların tamamını; sevgi evi, çocuk evi ve koruyucu aile hizmet modeline dönüştürmektedir. 2014 yılı sonuna kadar bitirilmesi gereken dönüşüm süreci, ülke genelindeki çoğu ilde tamamlanmıştır. Sadece İstanbul'da 5 yuva ve 2 yetiştirme yurdu halen hizmetlerine hizmete devam etmektedir. 2014 yılı sonuna kadar kurum bakımında olan çocukların büyük bir bölümünü koruyucu ailelerin yanına yerleştirmeyi hedeflemektedir (ASPB-2014).

Koruyucu aile olmak için başvurular il veya ilçe müdürlüklerine yapılabilmektedir. 28497 Sayılı yönetmeliğin m. 8-(1), koruyucu aile başvurusu sahibinin taşıması gereken koşullar ve istenen belgeleri düzenlemektedir.

Başvuru sahibinin:

- Türk vatandaşı olması ve Türkiye'de sürekli ikamet etmesi,

- 25-65 yaş aralığında bulunması,

- En az ilkokul düzeyinde eğitim almış olması,

- $\quad$ Düzenli gelire sahip olması. 
gerekmektedir. Yeni uygulamaya göre, koruyucu ailelere, (Tablo: 2) yerleştirilen çocuk sayısı ve yaşına göre değişen miktarda aylık peşin ödemeler yapılmaktadır. Ödemeler çocukların sağlık, giyim, eğitim veya kurs; okul servisi (153.-TL), meslek edinme kursları (1.302.-TL), Seviye Belirleme Sınavı (2.448.-TL) ve üniversite sinavı hazırlık (3.814.-TL) kursları için harcanmak üzere yapılmaktadır. Koruyucu ailelere ödenen ücret, ek gösterge dâhil en yüksek devlet memuru aylık göstergesinin (9500) memur maaş katsayısıyla çarpımıyla elde edilen rakamın sırasıyla \%50'si, \%75'i, \%80'i, \%85'i ve \%90'ı alınarak belirlenmektedir. Harçlıklar, kuruluş bakımındaki çocuklar için yapılan hesaplama ile belirlenmekte olup; memur maaş katsayısı, sırasıyla 600 (İlköğretim 1-4. sınıfi), 900 (İlköğretim 5-8. sınıfi), 1200 (Lise ve dengi okul) ve 2000 (Yükseköğrenime devam eden) gösterge rakamı ile çarpılarak bulunan miktar kadar ödeme yapılmaktadır. 2014 yılının 1. yarısı için katsayı 0,076998 olarak belirlenmiştir (ASPB-2013).

Koruyucu aile yanına yerleştirilen çocukların bakım, eğitim ve yetiştirilmelerine ilişkin harcamalara karşılık olmak üzere (talepte bulunan koruyucu ailelere), çocuk başına aylık yapılan net ödemeler Tablo: 2'de verilmiştir. Özel zorlukları veya ihtiyaçları bulunan ya da engelli çocuklar için aylık bakım ücreti özür ve yaş durumu dikkate alınarak belirtilen miktar \%50 artırılarak uygulanmaktadır.

Tablo: 2

Koruyucu Aile Aylık Ödeme Miktarları

\begin{tabular}{|l|r|r|r|r|r|}
\hline Yaş-Okul Durum & $\%$ & Aylık Bakım Ücreti & Gösterge & Aylık Harçlık & Aylık Toplam \\
\hline 0-3 Yaș & 50 & 365,74 & - & - & 365,74 \\
\hline 4-5 Yaş & 75 & 548,61 & - & - & 548,61 \\
\hline $\begin{array}{l}\text { 6-14 yaş } \\
\text { (̇llköğretim 1-4 ve 5-8 Sınıflar) }\end{array}$ & \multirow{2}{*}{80} & 585,18 & 600 & 46,20 & 631,38 \\
\hline 15-18 yaş (Lise ve Dengi) & 85 & 900 & 69,30 & 654,48 \\
\hline 19+ yaş (Yüksek Ö̆ğrenim) & 90 & 621,76 & 1200 & 92,40 & 714,16 \\
\hline
\end{tabular}

Kaynak: ASPB-2014 Not: 2014 yılının 1. yarlsı için katsayı: 0,076998.

Koruyucu aile hizmet modelinde; çocuğun bakımı, yetiştirilmesi ve eğitim sorumluluğunu, devlet ve koruyucu aile arasında paylaştırılırken; velayeti öz ailesine bırakılmaktadır. Koruyucu aile hizmeti, aşağıdaki dört farklı koruyucu aile modeli ile uygulanmaktadir:

- $\quad$ Akraba veya Yakın Çevre Koruyucu Aile Modeli,

- Süreli Koruyucu Aile Modeli,

- Geçici Koruyucu Aile Modeli,

- Uzmanlaşmış Koruyucu Aile Modeli.

Akraba veya yakın çevre koruyucu aile modeli; veli ya da vasi dışında kalan, kan bağı bulunan akrabalar ya da çocuğun iletişim içinde olduğu veya tanıdığı bakıcı, komşu 
gibi yakın çevresinde olan, (tercih etmeleri halinde) en az temel ana-baba eğitimleri kapsamında eğitim almış kişi ve ailelerin sağladığı bakım, olarak tanımlanmaktadır. Acil koruma gereken ya da hakkında hizmet planı oluşturulmamış, kuruluş bakımına yerleştirilmemiş ya da kendisi için planlanan hizmet modelinden çeşitli nedenlerle henüz yararlandırılamamış çocuklar için uygulanan bir modeldir. Süreli Koruyucu Aile Modeli, öz ailesi yanına kısa sürede döndürülme imkânı bulunmayan ya da kalıcı olarak aile yanına yerleştirilemeyen çocuklara, tercihen temel ana-baba eğitimleri ve Koruyucu Aile Birinci Kademe Eğitimini almış kişi ve ailelerin sağladığı bakım modelidir. Geçici koruyucu aile modeli, temel ana- baba eğitimleri ve Koruyucu Aile Birinci ve İkinci Kademe Eğitimini almış profesyonel kişi ve ailelerin sağladığı birkaç gün veya en fazla bir ay arasında değişen bakım sürecini ifade etmektedir. Uzmanlaşmış Koruyucu Aile Modeli ise; fiili olarak yeni uygulamaya başlanan bir modeldir. Özel zorlukları ve ihtiyaçları olan çocuklara yardımcı olabilecek, lisans eğitimine sahip olan veya eşlerden biri en az ilköğretim düzeyinde olmak üzere temel ana-baba eğitimleri, Koruyucu Aile Birinci Ve İkinci Kademe Eğitimlerini almış kişi ve ailelerin sağladığı bakım modelidir.

Devlet korumasındaki çocuk/gençlerin bakımında, koruyucu aile hizmetini veren aileler, çocuğun akraba ve yakın çevresinden olsun veya olmasın, devlet kurumlarıyla birlikte bütünleşik bir hizmet sunmaktadır. Çocuğun büyükbaba ve büyükannesinin, (akraba ve yakın çevre modeli) yanında koruyucu aile hizmeti aldığı durumda, fiziksel ihtiyaçları yanında okul, arkadaş ortamı ve sosyal ilişkilerini düzenleme, izleme, disipline etme ve hatta öz ailesiyle ilişkilerini normalleştirme sürecinde pozitif etki yaptığ 1 ve geri dönüş riskinin azlığına vurgu yapılmaktadır. Aynı zamanda çocuklara yönelik refah artırıcı her türlü hizmetin iyileştirilmesinin, koruyucu aile hizmetine katkı sağlayacağı ifade edilmektedir (Lee vd., 2012: 1827-8; Zinn, 2012: 605-6; Miller, 2013: 145-6).

Türkiye genelinde, 2014 Mayıs ayı itibariyle 4264 koruyucu aile başvurusu yapılmış, başvurusu kabul edilen, 3067 koruyucu aile yanına 3109 çocuk yerleştirilmiştir. Diğer başvuruların değerlendirme süreci devam ederken, 1092 ailenin başvuru için sırada beklediği bilgisi verilmiştir. Avrupa'daki uygulanma oranı \% $75^{\prime}$ lere ulaşan Uzmanlaşmış Koruyucu Aile Modeli, mevzuatta yer almasına karşın, ülke genelinde Çankırı ve Gümüşhane illerinde, iki aile ile uygulama olup, İstanbul'da henüz bu modelin uygulanmasına geçilememiştir. Geçici koruyucu aile modeli ülke genelinde yaygın uygulanan bir modeldir. Tablo: 3'de Türkiye geneli ve İstanbul'da uygulanan koruyucu aile modelleri ve yerleştirilen çocuk sayıları verilmektedir (ASPB-2014).

Koruyucu aile modelini düzenleyen ilgili mevzuata göre; Bakanlığın yetkilendirilmiş uzman personeli, yerleştirilen çocuğun ihmal ve istismara maruz kalmasını önlemek; öz ailesiyle ilişkisini takip etmek ve söz konusu hizmetin aksaklıklarını tespit edip geliştirmek amacıyla; çocuk, koruyucu aileyi, çocuğu ve öz ailesini, vakanın özelliklerine göre belirlenen aralıklarla, düzenli aralıklarla izlemektedir. 
Tablo: 3

Koruyucu Aile Modelleri ve Yerleștirilen Çocuk Sayıları

\begin{tabular}{|l|r|r|r|r|r|r|}
\hline & $\begin{array}{c}\text { Toplam } \\
\text { Yerleştirilen } \\
\text { Çocuk Sayısı }\end{array}$ & $\begin{array}{c}\text { Koruyucu } \\
\text { Aile Sayısı }\end{array}$ & $\begin{array}{c}\text { Akraba ve } \\
\text { Yakın Çevre } \\
\text { Koruyucu Aile } \\
\text { Modeli }\end{array}$ & $\begin{array}{c}\text { Süreli } \\
\text { Koruyucu } \\
\text { Aile Modeli }\end{array}$ & $\begin{array}{c}\text { Geçici } \\
\text { Koruyucu } \\
\text { Aile Modeli }\end{array}$ & $\begin{array}{c}\text { Uzmanlaşmış } \\
\text { Koruyucu Aile } \\
\text { Modeli } \\
\text { Model }\end{array}$ \\
\hline İstanbul & 335 & 307 & 50 & 285 & 0 & 0 \\
\hline Türkiye & 3109 & 3067 & 561 & 3 & 2543 & 2 \\
\hline
\end{tabular}

Kaynak: ASPB-2014 Revize: 24/07/2014.

Grafik: 1, Türkiye geneli ve İstanbul'da yerleştirilen çocukların yaş gruplarını ve Grafik: 2, cinsiyet dağılımını göstermektedir.

Grafik: 1

Koruyucu Aile Yanına Yerleştirilen Çocukların Yaş Aralığı Dağılımı

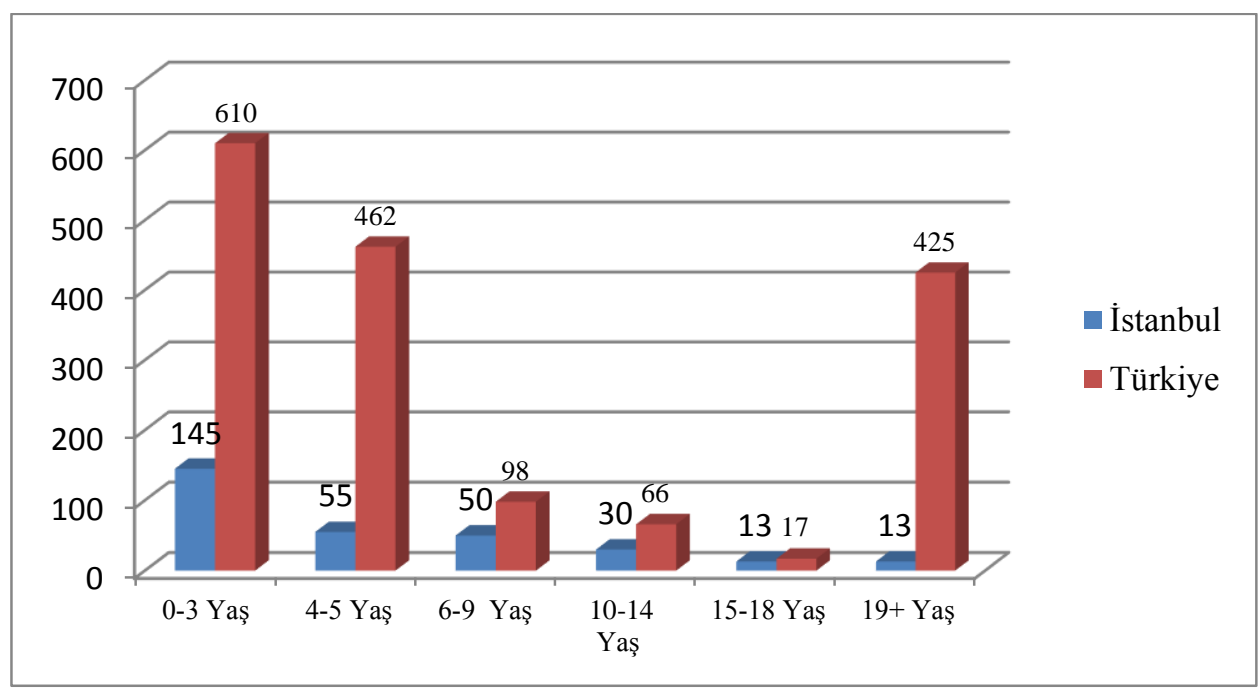

Kaynak: ASPB,2014.

Ailelerin tercih ettiği yaş gruplarının, göreceli olarak, koruyucu aile ve çocuk arasında bağlanma sorunlarının daha az yaşandığı (0-3) ve (4-5) yaş grupları aralığında yoğunlaştı̆̆ görülmektedir. Ayrıca çocukluktan ergenliğe geçiş sürecinde yaşanan sorunların yoğun olduğu (10-18) yaş aralığındaki çocuk ve genlerin daha az tercih edildiği gözlenmektedir. Bireysel fiziksel gelişimin tamamlandığı 19+ yaş aralığının tercih edilmesi de dikkat çekicidir.

Türk toplumundaki geleneksel ataerkil aile yapısında, çocuk sahibi olmak isteyen ailelerin, özellikle ilk çocukda, kız çocuklardan ziyade, erkek çocuklarını tercih ettiği 
bilinmektedir.Tarım toplumunun getirdiği kültürün klasik tercihi olan bu durumun, koruyucu ailelerin çocuk seçimlerinde değiştiği gözlenmektedir.

Grafik: 2'de görüldüğü gibi, koruyucu aile hizmetine talip olan ailelerin, geleneksel tercihlerin tersine bir eğilimle, çoğunlukla kız çocuklarını tercih ettikleri görülmektedir.

\section{Grafik: 2}

Koruyucu Aile Yanına Yerleştirilen Çocukların Cinsiyet Dağılımı

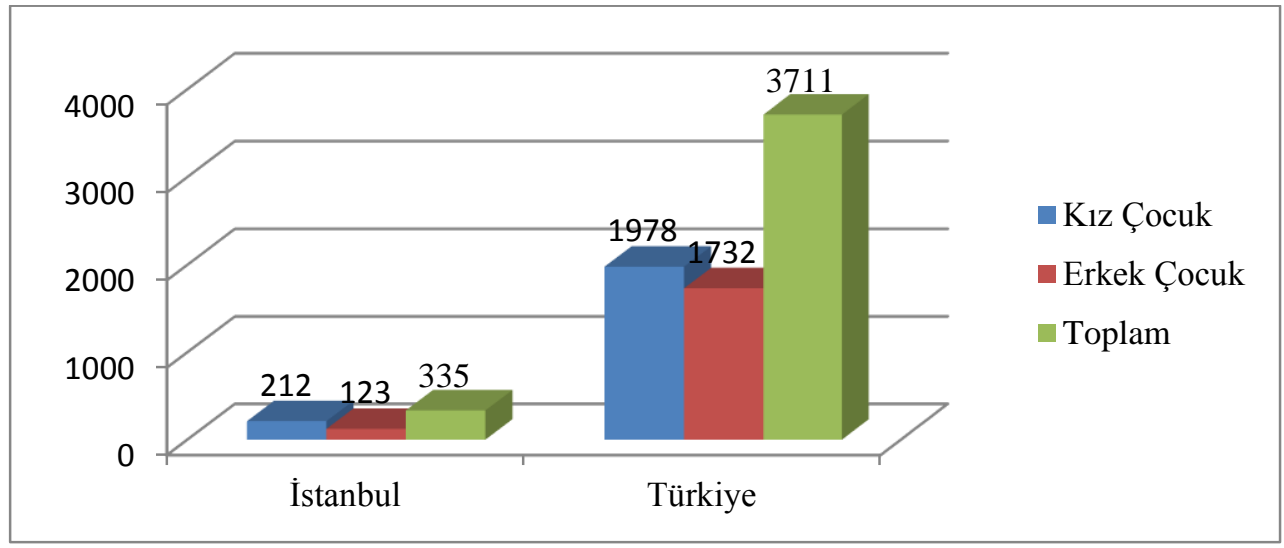

Kaynak: ASPB, 2014.

Koruyucu aile bakım modelinde; çocuk koruyucu aile yanına yerleştirildikten sonra, çocuğun kendisinden, koruyucu aileden ve/veya öz aileden kaynaklanan nedenlerle geri dönüşler yaşanabilmektedir. Koruyucu aile bakım modelinde öz aileye döndürülme ve çocuğun, koruyucu aile üyeleriyle iletişim ve uyum sorunu yaşaması gibi nedenler, koruyucu aile hizmetinin sonlandırılmasının ana nedenleri arasındadır. Bakanlık, bir taraftan çocuğun öz ailesine, sosyal ve maddi destek sağlayarak, onun fiziksel, ruhsal ve duygusal anlamda gelişimini sağlayacağı en iyi ortamdan uzaklaşmasını engellemeye çalışırken; diğer taraftan da, çocuk ve koruyucu aile üyeleri arasında yaşanan duygusal sorunların giderilmesi amacıyla, koruyucu aile eğitimlerini yaygınlaştırarak, çocukların kurum bakımından ziyade koruyucu aile yanında uzun süre kalabilmelerini hedeflemektedir.

\section{Sonuç ve Öneriler}

Ekonomik kalkınma ve sosyal gelişmenin ana belirleyicileri arasında olan beşeri sermaye, devletin temel unsurlarından olan millet/insan/birey unsurunu oluşturmaktadır. Bilgi ve beceri düzeyi yüksek bireyler, toplumun beşeri sermayesini zenginleştirmektedir. $\mathrm{Bu}$ bağlamda devlet, iyi yetişmiş ve topluma karşı sorumluluk sahibi bireye, klasik özgürlükler yanında; ruhsal, fiziksel ve sosyal anlamda gelişimini sağlayacak eğitim, sağlık 
güvenlik gibi sosyal imkânları sağlamakla yükümlüdür. Sosyal devlet anlayışının gereği olarak ayrıca devlet, söz konusu hizmetlerin kalitesini ve erişilebilirliğini artırma, özellikle de dezavantajlı bireylere/vatandaşlarına bu hizmetleri adil bir şekilde ulaştırma yükümlülüğ̈̈ altındadır.

Değişen toplumsal yapı içinde birey; göç, şehirleşme, sosyo-ekonomik değişim ve dönüşümler, işsizlik nedeniyle yaşanan sosyal durum değişikliklerinin sonucu olan yoksulluğun, ailenin yapısında ve fonksiyonlarında bozulmaya neden olmasının olumsuzluklarını yaşamaktadır. Sosyal yapıdaki değişim, yakın aile, sosyal çevresi ve devlet desteğinden yoksun kalan işsiz ve yoksul ailenin, yoksunluğunun hem nedeni hem de sonucu olmaktadır. Toplumun veya devletin desteğine erişim, ailenin her türlü güçlenmesine ve birçok bireyin ve özelliklede toplumun geleceği olan çocuğun hayatının kurtulmasına vesile olmaktadır.

Çocuğun/gencin korunması ve refahıyla ilgili her türlü kararı içeren kapsamlı bir hizmet alanı olarak çocuk bakımı, çocuğun içinde bulunduğu çevreden kaynaklanan istismar, ihmal gibi potansiyel riskleri değerlendirerek, bu riskleri en aza indirecek hizmetlerin tamamını ifade etmektedir. Hayatlarının ilk evrelerinde; istismar, ihmal, tacize maruz kalan çocuk/gençlerin, yaşadıkları travmalar ve olumsuzlukların sonraki yıllarında ortaya çıkacak gelişim geriliği, davranışsal ve mental sağlık problemlerine neden olduğu bilinmektedir.

Sosyal politikada, devlet koruması altındaki çocuk/gençlerin bakımında önemli bir hizmet modeli olan Koruyucu Aile Hizmetinin teşvik edilmesinin temelinde, demografik nedenler, aile yapısındaki dönüşümler gibi sosyal nedenler, yoksulluk gibi ekonomik faktörler, siyasî ve hukukî bir zemin olarak "sosyal devlet" ilkesi ve insanî gerekçeler sayılmaktadır. Son yıllarda tüm dünyada olduğu gibi, liberal ekonomik yapının da etkisiyle, mevcut hükümet, sosyal refah ve sosyal politika açısından, devlet koruması altındaki çocuk/gençlere yönelik karar ve uygulamaların temel aktörü olmaya devam etmektedir. Devlet, son döneme kadar korunmaya muhtaç çocuk/gençlere, yurt ve yuvalarda toplu olarak verilen bakım ve koruma hizmetinin ifasında, hem hizmetin kalitesini artırmak hem de maliyetlerini düşürmek amacıyla, sivil toplum kuruluşları ve vatandaşla işbirliğini tercih ve teşvik etmektedir.

Kurum bakımı, sadece Birleşmiş Milletler Çocuk Hakları Sözleşmesi'nde, çocuk için gerekli "koruma" ve yapılması gereken "işlem" ihtiyacını karşılamaktadır. Ancak kurum bakımı, aile hayatının vereceği psiko-sosyal ihtiyaç ve iyi olma/hissetme duygusunu ve çocuğun/gencin bulunduğu çevrede, sonraki hayatını karakterize edecek bir sosyalleşme ortamı verememektedir. Bu bağlamda koruyucu aile bakım hizmeti modelinin görece kurum bakımına tercih edilmesiyle ilgili tartışmalar artık daha da netleşerek, sosyal politikanın çocuk koruma ve bakımıyla ilgili stratejik hedeflerine yönelik, koruyucu aile hizmet modeli uygulamasına geçilmiştir. Akademik araştırmalar da, koruyucu aile yanında bakımın, çocuklar için kurum bakımından daha faydalı olduğunu; benlik gelişimi, kendine güven veya 
depresyona maruz kalma ve davranış problemleri açısından, öz ailesiyle kalan çocuklarla karşılaştırıldığında, bir farkının olmadığını kanıtlamaktadır.

\section{Kaynakça}

Akyüz, E. (2013), Çocuk Hukuku, Çocukların Hakları ve Korunması, Genişletilmiş 3. Baskı, 2013, Pegem Akademi, Ankara.

Aile ve Sosyal Politikalar Bakanlığı (2012), ASPB Bülteni, <http://www.sosyalyardimlar.gov.tr>, 23.08.2013.

Aile ve Sosyal Politikalar Bakanlığı (2012), “Türkiye'de Uygulanan Şartlı Nakit Transferi Programı'nın Fayda Sahipleri Üzerindeki Etkisinin Nitel ve Nicel Olarak Ölçülmesi”, T.C. Aile ve Sosyal Politikalar Bakanlığı, Sosyal Yardımlar Genel Müdürlüğü, Rapor, Ankara 2012, <http: //www.aile.gov.tr/tr/2161/Sartli-Nakit-Transferi-Programi>, 16.04.2013.

Aile ve Sosyal Politikalar Bakanlığı (2013), ASPB Bülteni, <http://istanbul.aile.gov.tr/tr>, 23.09.2013.

Aile ve Sosyal Politikalar Bakanlığı (2014), ASPB Bülteni, <http://www.koruyucuaile.gov.tr/tr/html/121/Mevzuat>, 23.07.2014.

Blythe, S. \& L.D. Jackson \& E.J. Halcomb \& L. Wilkes (2012), “The Stigma of Being a Long-Term Foster Carer", Journal of Family Nursing, 18(2): 234.

CB-Report, Child Welfare Information Gateway (2013), Foster Care Statistics 2011, Washington, DC: U.S. Department of Health and Human Services, Children's Bureau, <https://www.childwelfare.gov/>, 12.05.2013.

CSSP (2009), "Report of Center for the Study Social Policy”, Policy Matters: Setting and Measuring Benchmarks for State Policies, Promoting Child Safety, Permanence, and Well-Being Through Safe and Strong Families, Supportive Communities, and Effective Systems, $A$ Discussion Paper for the Policy Matters Project Center for the Study Social Policy, 1575 Eye Street, N.W., Suite 500 Washington, D.C. 2005.

Del Valle, J.F. \& M. López \& C. Montserrat \& A. Bravo (2009), “Twenty years of foster care in Spain: Pofiles, patterns and outcome", Children and Youth Services Review, 31, 847-853.

Ersöz, H.Y. (2006), “Sosyal Devletten Gönüllü Sivil Topluma”, Sosyal Politikalar Dergisi, Güz (01), 39-41.

Ersöz, H.Y. (2011), Sosyal Politikada Yerelleşme, İstanbul Ticaret Odası, Yayın No: 2010- 99, İstanbul, 2011, 237.

Koray, M. (2007), “Sosyal Politikanın Anlamı ve İşlevini Tartışmak”, Çalışma ve Toplum, 2007/4, $19-56$.

Karataş, K. (2007), “Türkiye'de Çocuk Koruma Sistemi ve Koruyucu Aile Uygulamaları Üzerine Bir Değerlendirme", Toplum ve Sosyal Hizmet, 18(2), 7-19.

Lee, S. \& M. Jonson-Reid \& B. Drake (2012), "Foster care re-entry: Exploring the role of foster care characteristics, in-home child welfare services and cross-sector services", Children and Youth Services Review, 34,1825-1833. 
Miller, C. Laurie (2013), “Adoption and Foster Family Care”, Section 13, Development- Behavioral Pediadrics, William Bacon Carey (Ed.), Crocker Coleman, Elias Feldman, 4. Bask1.

Mooney L.A. \& D. Knox \& C. Schacht (2012), “Understanding Social Problems”, Seventh Edition, MPS Limited, A Macmillan Company, ABD.

Özdemir, S. (2009), “ Küreselleşme ve Refah Devletleri Üzerindeki Etkileri”, Sosyal Siyaset Konferansları Dergisi, 59, 56-86.

Özdemir, S. (2007), Küreselleşme Sürecinde Refah Devleti, İstanbul Ticaret Odası Yayınları, Yayın No: 2007, 2. Bask1, 157.

Özgür, Ö. (2011), "Kurum Bakımı Altındaki Çocukları Anlamak ve Onlarla Çalışmak: Bağlanma Teorisinden Bir Bakış", e-Journal of New World Sciences Academy, Social Sciences, Makale No: 3C0062, 6 (1), 96-106.

Özler, M. (1995), ’Türkiye' de Anayasa ve Yasa Düzeyinde Sosyal Devletin Gelişimi: 1921-1983”, İstanbul Üniversitesi, Siyaset ve Sosyal Bilimler Anabilim Dalı, Yüksek Lisans Tezi.

Şimşek, S. (2004), “The Transformation of Civil Society in Turkey: From Quantity to Quality”, Turkish Studies, 5(3), 46-74.

Sommerfeldt, E.J. (2013), "The civility of social capital: Public relations in the public sphere, civil society, and democracy", Public Relations Review, 309, 280-289.

Suğur, N.S. \& E. Doğru (2010), "Koruma Altındaki Çocukların Aile ve Devlet Algısı Üzerine Bir Araştırma”, Siyasal Bilgiler Fakültesi Dergisi, 65(1), 115-133.

Tarabini, A. (2010), "Education and poverty in the global development agenda: Emergence, evolution and consolidation", International Journal of Educational Development, 30, 204-212.

Taşc1, F. (2010), "Yaşlılara Yönelik Sosyal Politikalar: İsveç, Almanya, İngiltere ve İtalya Örnekleri”, Çalışma ve Toplum, 1, 175-202.

Thoburn, J. (2009), "Reunification of children in out-of-home care to birth parents or relatives: A synthesis of the evidence on processes, practice and outcomes", Expertise für das Projekt: Pflegekinderhilfe in Deutschland, 2009.

TÜİK (2013), Yıllara, Yaş Grubu ve Cinsiyete Göre Nüfus, Genel Nüfus Sayımları - ADNKS, <http://www.tuik.gov.tr/UstMenu.do?metod=temelist>, 14.09.2013.

Vinnerljung, B.\& A. Hjern (2011), "Cognitive, educational and self-support outcomes of long-term foster care versus adoption. A Swedish national cohort study", Children and Youth Services Review, 33, 1902-1910.

Wood, G. \& I. Gough (2006), "A Comparative Welfare Regime Approach to Global Social Policy", World Development, 34 (10), 1696-1712.

Yolcuoğlu, İ.G. (2012), “Türkiye'de Sosyal Politika ve Sosyal Hizmetlerin Geliştirilmesi”, Toplum ve Sosyal Hizmet, 23 (2), 145-157.

Zinn, A. (2012), "Kinship foster family type and placement discharge outcomes", Children and Youth Services Review, 34, 602-614. 